\title{
OPTIMIZING SYSTEM OF RICE INTENSIFICATION PARAMETERS USING AQUACROP MODEL FOR INCREASING WATER PRODUCTIVITY AND WATER USE EFFICIENCY IN RICE PRODUCTION
}

\author{
Katambara, Z. ${ }^{l, *}$, F.C. Kahimba ${ }^{2}$, W.B. Mbungu ${ }^{2}$, R. Paul, M. Maugo ${ }^{3}$, F. Mhenga ${ }^{2}$ and H.F. Mahoo ${ }^{2}$ \\ ${ }^{I}$ Department of Civil Engineering, Mbeya University of Science and Technology, Mbeya, Tanzania. \\ ${ }^{2}$ Department of Agricultural Engineering and Land Planning, Sokoine University of Agriculture, Morogoro, \\ Tanzania. ${ }^{3}$ Ministry of Agriculture, Food Security and Cooperatives, Dar es Salaam, Tanzania. *Corresponding \\ author email: zkatambaral@gmail.com
}

\begin{abstract}
Producing more rice while using less water is among the calls in water scarce regions so as to feed the growing population and cope with the changing climate. Among the suitable techniques towards this achievement is the use of system of rice intensification (SRI), which has been reported as an approach that uses less water and has high water productivity and water use efficiency. Despite its promising results, the use of SRI practice in Tanzania is limited due to less knowledge with regard to the transplanting age, plant spacing, and minimum soil moisture to be allowed for irrigation, and alternate wetting and drying interval for various geographical locations. The AquaCrop crop water productivity model, which is capable of simulating crop water requirements and yield for a given parameter set, was used to identify suitable SRI parameters for Mkindo area in Morogoro region, Tanzania. Using no stress in soil fertility, plant spacings ranging from $5 \mathrm{~cm}$ to $50 \mathrm{~cm}$ were evaluated. Results suggest that the yield and biomass produced per ha increase with decreasing spacing from $50 \mathrm{~cm}$ to $20 \mathrm{~cm}$. Preliminary field results suggest that the optimum spacing is round $25 \mathrm{~cm}$. However, the model structure does not take into consideration number of tillers produced. As such, the study calls for incorporation of the tillering processes into AquaCrop model.
\end{abstract}

Keywords: SRI, rice cultivars, plant spacing, transplanting age, tillering.

\section{GREEN INVESTMENT: A STRATEGY FOR SUSTAINABLE ECONOMIC GROWTH AND INVESTMENT}

\author{
Jaya Shukla, ${ }^{1, *}$ and Gaurav Bajpai ${ }^{2}$ \\ ${ }^{1}$ Kigali Institute of Management Kigali, Rwanda. ${ }^{2}$ KIST, Kigali, Rwanda. Corresponding author: \\ js.jayashukla@gmail.com
}

\begin{abstract}
Sustainable economic development has become an important area of concern due to climatic change with its long term effects. Climatic change has posed several challenges for economic sustainability of economies. Now major development projects have to comply with international environmental norms. Failure to do so may result in the delay of a project, fines including penalties for environmental damage or charges for remedial action, that affect the viability of a project or the value of any security taken. This paper investigates with help of secondary date using descriptive statistical technique opportunities and challenges of green investment. Here it is developed into suitable model for developing economies for successfully adopting green investment without much cost to their economies. The paper concludes that green investment involving direct investment and portfolio investment in firms adopting and following environmental protection norms will lead to sustainable growth and investment for economy.
\end{abstract}

Keywords: Green Investment, Sustainable investment.

\section{SUSTAINABLE MANAGEMENT OF CAMEROON FORESTS RESOURCES: PROVIDING TIMBER WASTE TO THE POOR POPULATIONS AS ALTERNATIVE SOURCE OF ENERGY}

NOUMO FOKO Serge Benjamin

FSEG - The University of Yaoundé II, Yaoundé, Cameroon. E-mail: snoumo@yahoo.com 


\begin{abstract}
Cameroon is covered by about 20 million hectares of forests. Timber exploitation is the second source of external income after petroleum. Besides, Cameroon's forest has several other functions. Yet the threat to the very existence and survival of this forest is rapidly increasing due to overexploitation by logging companies and for firewood. Despite its usefulness, a substantial volume of the wood felled by timber exploiters is abandoned as waste to rot. This waste can be used as firewood by households even for building and making of furniture by small-scale users like carpenters if they had access to it.

This paper encourages the use of timber waste as an alternative to kerosene, which has become very expensive and unaffordable due to the general rise in the price of petroleum products in recent years. The overexploitation of forests can therefore be limited by putting the waste timber into use. It will go along to reduce freshly cut wood which is usually cut illegally and uncontrollably and which is a major source of depletion of forest resources. This project, once achieved will forever last because it will always generate revenue to the groups involve in the collection and the distribution of forest waste which will make money from sales even if they were to sell cheaper since the major cost is transportation and the waste wood is also cheap to obtain from the logging companies or even costless since they have less interest in it.
\end{abstract}

\title{
ECONOMIC IMPACTS OF CLIMATE CHANGE: A MICRO-LEVEL EVIDENCE FROM NIGERIAN RICE AGRICULTURE
}

\author{
Joshua Ajetomobi ${ }^{l, *}$, Ajiboye Abiodun ${ }^{2}$ and Rashid Hassan ${ }^{3}$ \\ ${ }^{l}$ Department of Agricultural Economics, Ladoke Akintola University of Technology, Ogbomoso, Nigeria. \\ ${ }^{2}$ Department of Agricultural Economics, Ladoke Akintola University of Technology, Ogbomoso, Nigeria. ${ }^{3}$ Director \\ and Professor, Centre for Environmental Economics and Policy in Africa and Department of Economics, University \\ of Pretoria, Pretoria South Africa. Corresponding author: jsegun2002@yahoo.com
}

\begin{abstract}
This study employed the Ricardian approach to test the relative importance of climate normals (average longterm temperature and precipitation) in explaining the value of farm land used for rice production under irrigation and dry land conditions. A survey was done by interviewing 1200 rice farmers from 20 rice producing states in Nigeria. The states cover all the six geopolitical zones in the country. The results indicate that increase in temperature will reduce land rent per hectare for dry land rice farms while it increases the land rent for irrigated rice farms. Increase in precipitation on the other hand will cause a rise in land rent for both dry land and irrigated rice farms. The results clearly demonstrate irrigation as a significant techniques used by the farmers to adapt to the climate change.
\end{abstract}

JEL CODES: Q12, Q25

Keywords: Climate change, Irrigation, Land value, Rice, Nigeria.

\section{ВОЗМОЖНОСТИ ИСПОЛЬЗОВАНИЯ ЦИФРОВЫХ МОДЕЛЕЙ РЕЛЬЕФА В УПРАВЛЕНИИ ЗЕМЕЛЬНЫМИ РЕСУРСАМИ РЕГИОНА}

\author{
К. С. Тесленок, С. А. Тесленок \\ ФГБОУ ВПО «Мордовский государственный университет им. Н.П. Огарева», Географический \\ факультет \\ ул. Советская, 24, г. Саранск, Россия, 430011 \\ E-mail: kirilltesl@mail.ru,teslserg@mail.ru
}

\section{POSSIBILITY OF USING DIGITAL TERAIN MODELS FOR LAND MANAGEMENT IN THE REGION}

\author{
K. S. Teslenok, S. A. Teslenok \\ N. P. Ogarev Mordovian State University, Faculty of Geography \\ Sovetskaya St., 24, Saransk, Russia, 430011 \\ E-mail: kirilltesl@mail.ru,teslserg@mail.ru
}

